\title{
A New Cadinane Sesquiterpene with Significant Anti-HIV-1 Activity from the Cultures of the Basidiomycete Tyromyces chioneus
}

\author{
Dong-Ze Liu, Fei Wang, Liu-Meng Yang, Yong-Tang Zheng, Ji-Kai Liu
}

Received: February 12, 2007 / Accepted: May 16, 2007

(C) Japan Antibiotics Research Association

\begin{abstract}
A new cadinane sesquiterpene $(4 \beta, 14-$ dihydroxy- $6 \alpha, 7 \beta H$-1(10)-cadinene, 1) was isolated from the cultures of the basidiomycete, Tyromyces chioneus. Its structure was established on the basis of spectral measurements (MS, IR, 1D and 2D NMR experiments). 1 showed significant anti-HIV-1 activity with $\mathrm{EC}_{50}=3.0 \mu \mathrm{g} / \mathrm{ml}$ $(\mathrm{SI}=25.4)$.
\end{abstract}

Keywords Tyromyces chioneus, culture broth, cadinane sesquiterpene, anti-HIV-1

\section{Introduction}

Yunnan Province, southwest of China, is one of the areas with the richest and most diverse bioresources in the world. Among these bioresources, fungi produce a broad variety
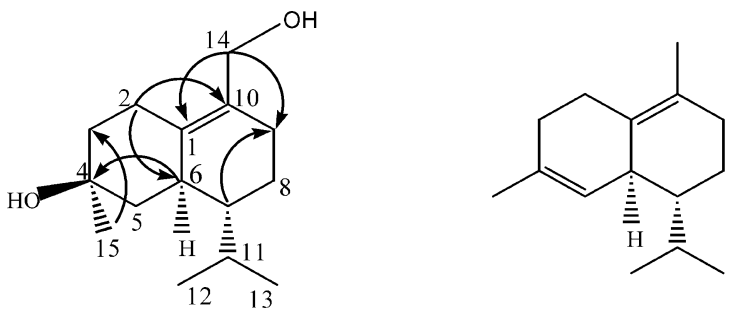

4ß,14-dihydroxy-6 $\alpha, 7 \beta H$-1(10)-cadinene(1) 1(10),4-cadinadiene(2)

Fig. $\mathbf{1}$ Structures of $\mathbf{1}$ and $\mathbf{2}$, and key HMBC correlations of 1. of secondary metabolites. Tyromyces chioneus belonging to order Polyporales of the family Polyporaceae is an inedible fungi and mainly occurs on wood as a substrate. So far, little work has been done on the chemical constituents of $T$. chioneus. As one part of our search for naturally occurring bioactive metabolites from the higher fungi in Yunnan province [1 6], a new cadinane sesquiterpene (1) was isolated from the cultures of the basidiomycete $T$. chioneus. In this paper, we describe the isolation and structure elucidation of $\mathbf{1}$ as well as its anti-HIV-1 activity.

\section{Materials and Methods}

\section{General}

Optical rotation was measured on an Horiba SEPA-300 polarimeter. IR spectra were obtained on a Bruker Tensor 27 instrument as $\mathrm{KBr}$ pellets. NMR spectra were recorded on Bruker AV-400 and Bruker DRX-500 spectrometers in $\mathrm{CD}_{3} \mathrm{OD}$ and $\mathrm{CDCl}_{3}$ solvents with TMS as an internal standard. EI-MS was recorded with a VG Autospec-3000 spectrometer. HRESI-MS was recorded with an API QSTAR Pulsar 1 spectrometer.

Silica gel (200 300 mesh, Qingdao Marine Chemical Inc., China) and Sephadex LH-20 (Amersham Biosciences, Sweden) were used for column chromatography. Fractions were monitored by TLC and spots were visualized by heating silica gel plates sprayed with $10 \% \mathrm{H}_{2} \mathrm{SO}_{4}$ in ethanol.
J.-K. Liu (Corresponding author), D.-Z. Liu, F. Wang: State Key Laboratory of Phytochemistry and Plant Resources in West China, Kunming Institute of Botany, Chinese Academy of Sciences, Kunming 650204, China, E-mail: jkliu@mail.kib.ac.cn
D.-Z. Liu, F. Wang: Graduate University of Chinese Academy of Sciences, Beijing 100049, China

L.-M. Yang, Y.-T. Zheng: Kunming Institute of Zoology, Chinese Academy of Sciences, Kunming 650223, China 


\section{Fungal Material}

The basidiomycete T. chioneus was collected at Ailao Mountain of Yunnan Province, China, in July 2003 and identified by Prof. Mu Zang, Kunming Institute of Botany, Chinese Academy of Sciences (CAS). The voucher specimen was deposited at the Herbarium of Kunming Institute of Botany, CAS.

\section{Fermentation and Isolation}

The culture medium consisted of potato (peeled) $200 \mathrm{~g}$, glucose $20 \mathrm{~g}, \mathrm{KH}_{2} \mathrm{PO}_{4} 3 \mathrm{~g}, \mathrm{MgSO}_{4} \cdot 7 \mathrm{H}_{2} \mathrm{O} 1.5 \mathrm{~g}$, citric acid $0.1 \mathrm{~g}$ and thiamine hydrochloride $10 \mathrm{mg}$ in 1 liter of deionized water. Reagent bottles were used as shaker flasks (size: $500 \mathrm{ml}$; volume of media: $300 \mathrm{ml}$ ). The $\mathrm{pH}$ was adjusted to 6.5 before autoclaving. Fermentation was carried out on a shaker at $22^{\circ} \mathrm{C}$ and $150 \mathrm{rpm}$ for 10 days.

The whole culture broth of $T$. chioneus (12 liters) was filtered and then extracted twice with EtOAc. The organic layer was concentrated in vacuo to give an oily residue $(1.3 \mathrm{~g})$ that was applied to a silica gel column, which was eluted stepwise with a $\mathrm{CHCl}_{3}-\mathrm{MeOH}$ solvent system. Fr. III (19 mg), eluted with $\mathrm{CHCl}_{3}-\mathrm{MeOH}(100: 1, \mathrm{v} / \mathrm{v})$, was further purified by repeated chromatography on a Sephadex LH-20 column eluted with $\mathrm{CHCl}_{3}-\mathrm{MeOH}(1: 1, \mathrm{v} / \mathrm{v})$ to yield $1(8.5 \mathrm{mg})$.

\section{Physico-chemical Properties}

$4 \beta, 14$-dihydroxy-6 $\alpha, 7 \beta H$-1(10)-cadinene (1). Colorless Oil; $[\alpha]_{\mathrm{D}}^{29.8}-20.3(c 0.8, \mathrm{MeOH})$; IR $v_{\max }(\mathrm{KBr}) \mathrm{cm}^{-1}$ : 3440, 2959, 2927, 2870, 1630, 1063; HRESI-MS (+), $\mathrm{m} / \mathrm{z}$ 261.1834 $[\mathrm{M}+\mathrm{Na}]^{+}$(calcd. for $\mathrm{C}_{15} \mathrm{H}_{26} \mathrm{O}_{2} \mathrm{Na}, 261.1830$ ); EI-MS $(70 \mathrm{eV}) \mathrm{m} / z$ (rel. int.): $220(12)\left[\mathrm{M}-\mathrm{H}_{2} \mathrm{O}\right]^{+}, 202$ (13), 189 (13), 177 (100), 159 (45), 147 (27), 133 (25), 119 (40); ${ }^{1} \mathrm{H}-\mathrm{NMR}\left(\mathrm{CD}_{3} \mathrm{OD}\right)$ and ${ }^{13} \mathrm{C}-\mathrm{NMR}\left(\mathrm{CD}_{3} \mathrm{OD}\right.$ and $\mathrm{CDCl}_{3}$ ): see Table 1 .

\section{Reagents and Cell Culture}

AZT (=3'-azido-3'-deoxythymidine) and MTT (=3-(4,5dimethylthiazol-2-yl)-2,5-diphenyltetrazolium bromide) were purchased from Sigma. Cells were donated by the Medical Research Council (MRC), AIDS Reagent Project, UK, and grown in RPMI-1640 medium supplemented with $10 \%$ heat-inactivated fetal calf serum (Gibro), $2 \mathrm{mM}$ L-glutamine, $10 \mathrm{mM}$ HEPES (=4-(2hydroxyethyl) piperazine-1-ethanesulfonic acid), $50 \mu \mathrm{M}$ 2-mercaptoethanol, 100,000 IU/ml penicillin, and $100 \mu \mathrm{g} / \mathrm{ml}$ streptomycin sulfate. All cells and virus were stored and resuscitated by common methods.

\section{Cytotoxicity of Compound 1 on C8166 Cells}

C8166 was one of the host cells for HIV-1. On a microtier plate, $100 \mu \mathrm{l}$ of $4 \times 10^{5} / \mathrm{ml}$ cells were seeded. Then $100 \mu \mathrm{l}$ of various concentrations of $\mathbf{1}$ was added and the cells were incubated at $37^{\circ} \mathrm{C}$ in a humidified atmosphere of $5 \% \mathrm{CO}_{2}$ for 72 hours. The cellular toxicity was assessed by an MTT colorimetric assay, the plates were read with a Bio-Tek ELx 800 ELISA reader at $595 / 630 \mathrm{~nm}$, and the $50 \%$ inhibitory concentration $\left(\mathrm{IC}_{50}\right)$ was calculated.

\section{Cytopathic-Effect (CPE) Inhibition Assay of 1}

In the presence of $100 \mu \mathrm{l}$ of various concentrations of $\mathbf{1}$, C8166 cells $\left(4 \times 10^{5} / \mathrm{ml}\right)$ were infected with $\mathrm{HIV}-1_{\text {IIIB }}$ at a multiplicity of infection (M.O.I) of 0.06 . The final volume was $200 \mu \mathrm{l}$. The plates were incubated in a humidified incubator at $37^{\circ} \mathrm{C}$ and $5 \% \mathrm{CO}_{2}$. AZT (Sigma Chemical Co.) was used for drug control. After 3 days of culture, the cytopathic effect was measured by counting the number of syncytia (multinucleated giant cells) in each well under an inverted microscope, and the $50 \%$ effective concentration $\left(\mathrm{EC}_{50}\right)$ was calculated.

\section{Results and Discussion}

1 was obtained as an oil. Based on positive ion HRESI-MS $\left([\mathrm{M}+\mathrm{Na}]^{+} m / z 261.1834\right.$, calcd. for 261.1830) and NMR spectra data, the molecular formula was determined to be $\mathrm{C}_{15} \mathrm{H}_{26} \mathrm{O}_{2}$, corresponding to 3 degrees of unsaturation. The IR spectrum indicated the presence of hydroxyl group at $3440 \mathrm{~cm}^{-1}$ and $\mathrm{C}=\mathrm{C}$ double bond at $1630 \mathrm{~cm}^{-1}$. The ${ }^{1} \mathrm{H}-$ NMR spectrum (Table 1) exhibited one methylene proton bearing a hydroxyl group $\left[\delta_{\mathrm{H}} 3.98(1 \mathrm{H}, \mathrm{d}, J=11.6 \mathrm{~Hz}), 4.11\right.$ $(1 \mathrm{H}, \mathrm{d}, J=11.6 \mathrm{~Hz})$ and three methyl signals due to one tertiary methyl group $\left[\delta_{\mathrm{H}} 1.31(3 \mathrm{H}, \mathrm{s})\right]$ and two secondary methyl groups $\left[\delta_{\mathrm{H}} 0.97(3 \mathrm{H}, \mathrm{d}, J=6.8 \mathrm{~Hz}), 0.81(3 \mathrm{H}, \mathrm{d}\right.$, $J=6.8 \mathrm{~Hz})]$.

The ${ }^{13} \mathrm{C}$-NMR and DEPT spectra (Table 1 , in $\mathrm{CD}_{3} \mathrm{OD}$ ) displayed 15 carbon resonances, including three methine carbons $\left(\delta_{\mathrm{C}} 47.7,39.7,28.7\right)$, six methylene carbons $\left(\delta_{\mathrm{C}} 62.4,48.3,41.6,28.7,27.4,22.4\right)$, two olefinic carbons $\left(\delta_{\mathrm{C}} 137.0,130.3\right)$, one quaternary carbon $\left(\delta_{\mathrm{C}} 71.3\right)$ and three methyl carbons $\left(\delta_{\mathrm{C}} 25.6,22.1,17.1\right)$. These observations, in combination with the molecular formula, indicated the presence of two $\mathrm{OH}$ groups and two rings. The similarity of ${ }^{13} \mathrm{C}-\mathrm{NMR}$ data of partial structure for $\mathbf{1}$ $\left[\mathrm{C}-1 \quad\left(\delta_{\mathrm{C}} 129.5\right), \mathrm{C}-2\left(\delta_{\mathrm{C}} 26.6\right), \mathrm{C}-6\left(\delta_{\mathrm{C}} 38.5\right), \mathrm{C}-7\right.$ $\left(\delta_{\mathrm{C}} 46.0\right), \mathrm{C}-8\left(\delta_{\mathrm{C}} 21.7\right), \mathrm{C}-12\left(\delta_{\mathrm{C}} 16.7\right)$, and C-13 $\left.\left(\delta_{\mathrm{C}} 21.3\right)\right]$ with those of $1(10), 4$-cadinadiene $(2)$ [7] [C-1 $\left(\delta_{\mathrm{C}} 129.9\right), \mathrm{C}-2\left(\delta_{\mathrm{C}} 26.7\right), \mathrm{C}-6\left(\delta_{\mathrm{C}} 39.5\right), \mathrm{C}-7\left(\delta_{\mathrm{C}} 45.4\right), \mathrm{C}-$ $8\left(\delta_{\mathrm{C}} 21.2\right), \mathrm{C}-12\left(\delta_{\mathrm{C}} 15.6\right)$, and $\left.\mathrm{C}-13\left(\delta_{\mathrm{C}} 21.7\right)\right]$ suggested that 1 might be a cadinane-type sesquiterpene. This hypothesis was confirmed by careful analysis of ${ }^{1} \mathrm{H}-{ }^{1} \mathrm{H}$ 
Table 1 NMR spectral data for 1 and 2. ( $\delta$ in ppm, $J$ in $\mathrm{Hz}$ )

\begin{tabular}{|c|c|c|c|c|}
\hline \multirow{2}{*}{ Position } & \multicolumn{2}{|l|}{$1\left(\mathrm{CD}_{3} \mathrm{OD}\right)$} & \multirow{2}{*}{$\frac{1\left(\mathrm{CDCl}_{3}\right)}{\delta(\mathrm{C})}$} & \multirow{2}{*}{$\frac{2\left(\mathrm{CDCl}_{3}\right)}{\delta(\mathrm{C})}$} \\
\hline & $\delta(\mathrm{H})$ & $\delta(\mathrm{C})$ & & \\
\hline 1 & - & 130.3 (s) & 129.5 & 129.9 \\
\hline 2 & $\begin{array}{l}2.78(1 \mathrm{H}, \mathrm{ddd}, 14.0,3.2,2.4) \\
1.78(1 \mathrm{H}, \mathrm{m})\end{array}$ & $27.4(t)$ & 26.6 & 26.7 \\
\hline 3 & $1.41(1 \mathrm{H}, \mathrm{m}), 1.71(1 \mathrm{H}, \mathrm{m})$ & $41.6(t)$ & 41.0 & 31.9 \\
\hline 4 & - & 71.3 (s) & 70.9 & 133.9 \\
\hline 5 & $1.94(1 \mathrm{H}, \mathrm{m}), 1.12(1 \mathrm{H}, \mathrm{m})$ & $48.3(t)$ & 47.5 & 124.6 \\
\hline 6 & $1.94(1 \mathrm{H}, \mathrm{m})$ & $39.7(d)$ & 38.5 & 39.5 \\
\hline 7 & $1.03(1 \mathrm{H}, \mathrm{m})$ & $47.7(d)$ & 46.0 & 45.4 \\
\hline 8 & $1.65(1 \mathrm{H}, \mathrm{m}), 1.19(1 \mathrm{H}, \mathrm{m})$ & $22.4(\mathrm{t})$ & 21.7 & 21.2 \\
\hline 9 & $2.03(1 \mathrm{H}, \mathrm{m}), 2.19(1 \mathrm{H}, \mathrm{brd}, 16.9)$ & $28.7(\mathrm{t})$ & 27.9 & 32.3 \\
\hline 10 & - & 137.0 (s) & 136.3 & 124.1 \\
\hline 11 & $1.84(1 \mathrm{H}, \mathrm{m})$ & $28.7(d)$ & 27.5 & 26.7 \\
\hline 12 & $0.81(3 \mathrm{H}, \mathrm{d}, 6.8)$ & $17.1(q)$ & 16.7 & 15.6 \\
\hline 13 & $0.97(3 \mathrm{H}, \mathrm{d}, 6.8)$ & $22.1(q)$ & 21.3 & 21.7 \\
\hline 14 & $3.98(1 \mathrm{H}, \mathrm{d}, 11.6), 4.11(1 \mathrm{H}, \mathrm{d}, 11.6)$ & $62.4(\mathrm{t})$ & 62.7 & 18.4 \\
\hline 15 & $1.31(3 \mathrm{H}, \mathrm{s})$ & $25.6(q)$ & 25.6 & 23.5 \\
\hline
\end{tabular}

COSY, HSQC, and HMBC spectrum.

Analysis of ${ }^{1} \mathrm{H}-{ }^{1} \mathrm{H}$ COSY and HSQC spectrum led to the identification of the partial structures $\mathrm{CH}_{2}(2)-\mathrm{CH}_{2}(3)$, $\mathrm{CH}_{2}(8)-\mathrm{CH}_{2}(9)$ and $\mathrm{CH}_{3}(12)-\mathrm{CH}(11)-\mathrm{CH}_{3}(13)$. The HMBC correlations of Me-15 $\left(\delta_{\mathrm{H}} 1.31\right)$ with C-3, C-4 and $\mathrm{C}-5$, and $\mathrm{H}-14$ with $\mathrm{C}-1, \mathrm{C}-9$ and $\mathrm{C}-10$ indicated that $\mathrm{C}-3$, $\mathrm{C}-5, \mathrm{Me}-15$ and $\mathrm{C}-1, \mathrm{C}-9, \mathrm{C}-14$ were connected to the quaternary carbons $\mathrm{C}-4$ and $\mathrm{C}-10$, respectively. Additional HMBC experiments showed the critical correlations from H-2 to C-1, C-3, C-6 and C-10, from H-7 to C-6 and C-9, from H-6 to C-4, and from both Me-12 $\left(\delta_{\mathrm{H}} 0.81\right)$ and Me-13 $\left(\delta_{\mathrm{H}} 0.97\right)$ to $\mathrm{C}-7$ and $\mathrm{C}-11$. The above analysis determined the planar structure of $\mathbf{1}$. The relative configurations of $\mathbf{1}$ were deduced from analysis of the ROESY spectrum, which shows cross-peaks of H-6 with Me-12 and Me-15, H-8 $\alpha\left(\delta_{\mathrm{H}} 1.65\right)$ with Me-13, and H-7 with $\mathrm{H}-9 \beta\left(\delta_{\mathrm{H}} 2.19\right)$ indicating that $\mathrm{H}-6$ and Me-15 were $\alpha$-oriented, while H-7 was $\beta$-oriented. In the light of the evidence mentioned above, the structure of 1 was determined as $4 \beta, 14$-dihydroxy- $6 \alpha, 7 \beta H$-1(10)-cadinene.

1 showed cytotoxicity against C8166 cells $\left(\mathrm{IC}_{50}=76.9 \mu \mathrm{g} / \mathrm{ml}\right)$ and significant anti-HIV-1 activity with $\mathrm{EC}_{50}=3.0 \mu \mathrm{g} / \mathrm{ml}$ and SI (selectivity index) 25.4.
Acknowledgements This project was supported by Chinese Academy of Sciences (KSCX1-YW-R-24; KSCX2-YW-G-025).

\section{References}

1. Liu JK. Natural Terphenyls: Developments since 1887. $\mathrm{N}$ Containing compounds of macromycetes. Chem Rev 106: 2209-2223 (2006)

2. Liu JK. $N$-Containing compounds of macromycetes. Chem Rev 105: 2723-2744 (2005)

3. Liu JK. Biologically active substances from mushrooms in Yunnan, China. Heterocycles 57: 157-167 (2002)

4. Wang XN, Tan RX, Liu JK. Xylactam, a new nitrogencontaining compound from the fruiting bodies of ascomycete Xylaria euglossa. J Antibiot 58: 268-270 (2005)

5. Luo DQ, Wang F, Bian XY, Liu JK. Rufuslactone, a new antifungal sesquiterpene from the fruiting bodies of the basidiomycete Lactarius rufus. J Antibiot 58: 456-459 (2005)

6. Shao HJ, Qing C, Wang F, Luo DQ, Liu JK. A new cytotoxic lanostane triterpenoid from the basidiomycete Hebeloma versipelle. J Antibiot 58: 828-831 (2005)

7. Barrfro AF, Sanchez JF, Oltra JE, Altarejos J, Ferrol N, Barragan A. Phytochemistry 30: 1151-1154 (1991) 